\title{
AUTOMATIC MORPHEMIC ANALYSIS IN THE CORPUS OF THE UKRAINIAN LANGUAGE: RESULTS AND PROSPECTS
}

\author{
OKSANA ZUBAN \\ Taras Shevchenko National University of Kyiv, Ukraine
}

\begin{abstract}
ZUBAN, Oksana: Automatic Morphemic Analysis in the Corpus of the Ukrainian Language: Results and Prospects. Journal of Linguistics, 2017, Vol. 68, No 2, pp. 415 - 425.
\end{abstract}

\begin{abstract}
The article describes theoretical issues, principles of constructing and functioning of the Automated System of Morphemic and Derivational Analysis (ASMDA). The ASMDA system performs the following functions: 1) information system; 2) automatic morphemic annotation of text; 3) automatic linguistic constructor for frequency dictionaries. Description of the use of ASMDA as an automatic morphemic analyser of Ukrainian texts' lexicon is in the centre of attention; this article also describes structure as well as search and classification options of electronic morphemic dictionaries presented in linguistic research system of the Corpus of the Ukrainian language.

Keywords: Morphemic-Derivational database, Corpus of the Ukrainian language, the morphic segmentator of the Ukrainian text, Electronic dictionary of frequency, automatic morphemic analysis.
\end{abstract}

\section{INTRODUCTION}

Most of the corpora of Slavic languages do not deal with text annotation at morphemic level, that is why the methodology of computer modelling at morphemic level of text structure is not developed enough in modern corpus linguistics. Corpus of the Ukrainian language [9] is a research tool directed to solve a wide class of linguistic problems, particularly in the field of morphemics and word formation.

The practice and theory of creating automated databases are being successfully developed in the field of morphemics and word formation in modern Ukrainian computational linguistics: Morphemic-Derivational database of the Ukrainian Language [8], created in the Department of Structural and Mathematical Linguistics at the Academy of Sciences of Ukraine; Automated System of Morphemic and Derivational Analysis (ASMDA) [1], [2], [5] created by the staff of Computational Linguistics Laboratory at the Taras Shevchenko National University of Kyiv.

These two morphemic-derivational databases have different tasks and, accordingly, are based on different techniques. Morphemic-Derivational database of the Ukrainian language is designed to function as a kind of guide for a researcher in the field of linguistics, and it is undoubtedly extremely important for organizing a fullscale study of language, but it is static, it can not be used in a mode of automated text analysis. Automated System of Morphemic and Derivational Analysis (ASMDA) is an electronic linguistic product that performs automatic morph segmentation of initial word forms (lemmatized tokens) from the text, and has the status of dynamic search engine; it can find information about morphemic language units from any parametrized text presented in the Corpus of the Ukrainian language in an automatic or an automated mode. 
The aim of this article is to describe methodological issues, structure and functions of the ASMDA.

\section{STRUCTURE AND STAGES OF CREATION OF MORPHEMIC DATABASE (MDB) OF ASMDA}

The MDB of ASMDA system was based on I. T. Yatsenko's dictionary of morphemes [7]. One can define several stages of constructing ASMDA that aims at solving different tasks.

$1^{\text {st }}$ stage of MDB construction: 1) compilation of the database of morphemic word structure, where $\approx 170,000$ of words were segmented into morphemes in automated mode; 2 ) compilation of the database of allomorphic roots $(\approx 2,500$ roots); 3) compilation of the database of homonymic roots $(\approx 3,100$ roots $)$. The description of these tasks' automation and the obtained results are presented in the publications of the project authors [1], [2], [5], [13], [14].

$2^{\text {nd }}$ stage of MDB construction: 1) replenishment of MDB with new vocabulary, which has been automatically chosen from the texts of the Corpus of the Ukrainian language; at present the list of MDB contains $\approx 200,000$ words; 2) ascribing the meaning and functions in morphemic word structure to each affixal morpheme of a word; 3) identification of a minimal derivational pair, where the analysed affix fulfills a word-formation function; 4) identification of morphonological phenomena in morphemic word structure of each de-rivative.

Today the MDB consists of six interrelated databases: 1) a database of morphemic word structure containing $\approx 200,000$ words; 2 ) a database of allomorphic roots ( $\approx 2,500$ roots); 3 ) a database of homonymic roots $(\approx 3,100$ roots); 4 ) a database of allomorphic affixes (in progress); 5) a database of homonymic affixes (in progress); 6) a database of morphonological alternations (in progress). The compilation of MDB is fulfilled online in automated mode with the help of a useful computer tool, which is provided by morfem.exe system (see Fig. 1).

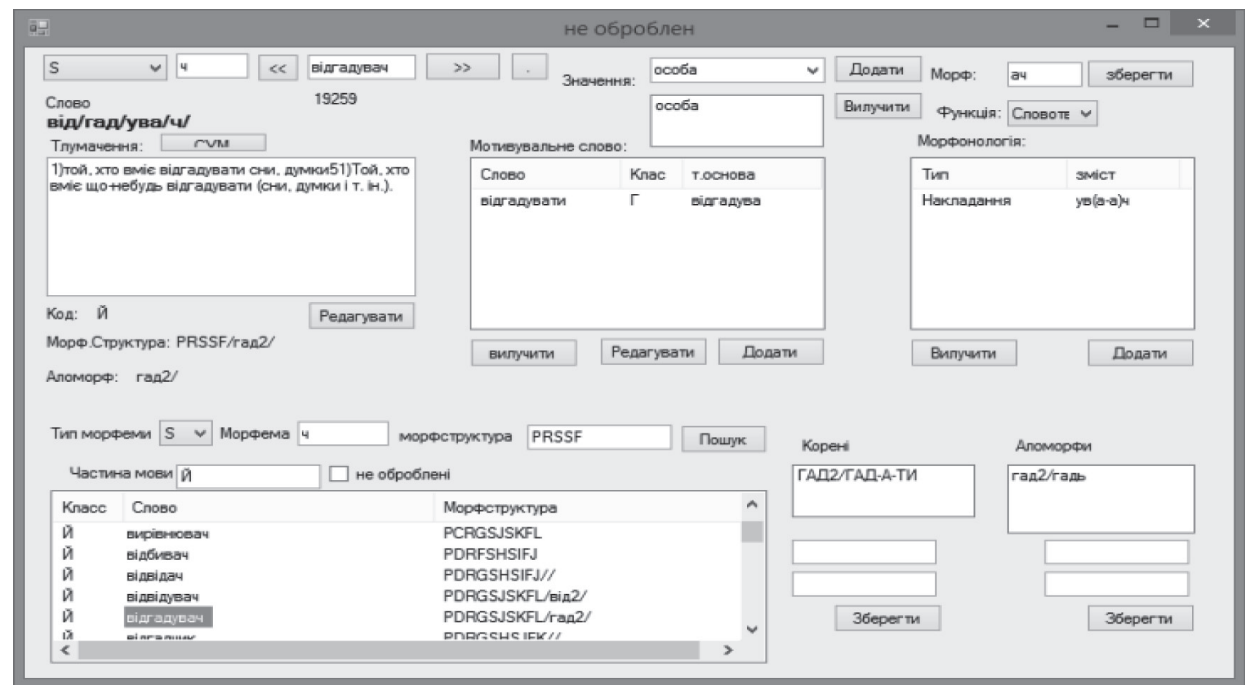

Fig. 1. Interface of the electronic card of morfem.exe system 


\subsection{Linguistic Issues of Modelling Morphemic Word Structure}

The main linguistic task in the process of the MDB compilation was to define morphemic structure of words in Ukrainian language - a procedure of morphemic analysis.

Active development of theory and practice of derivational analysis in comparison to the morphemic one caused the definition of morphic word structure in terms of derivational analysis. Such methodology uses a notion of morphic word structure as a result of sequential derivational acts - a defined morph has to represent one derivational tact. It is contrary to the traditional definition of morpheme as an indivisible minimal linguistic sign, because it leads to legitimation of complex morphemes (polymorphemes [10]), and it also causes ambiguous morphic segmentation in different dictionaries and grammars.

Morphic word structure cannot always be explained by derivational processes, and according to its quantitative and morphic components does not necessarily represent morphic boundaries that emerge in derivational structures: 1) derivational formants may consist of several morphs; 2) non-derived word stems may also be divided into morphs. The morphs are determined not according to the derivational relations, but on the basis of distributional and paradigmatic relations of these morphs in the system of morphemics as a whole; it allows to use analogy method in morphemic segmentation of words. To sum up, the morphic structure of the word form may be considered as a stable structure which is not constructed, but is inherited by derivative from its analogy example [3, p. 58].

Typical nature of morphemic structures, regular repetition and reproducibility in words gives an opportunity to determine them as a special type of language units - ontological units of structural nature at morphemic level of language system. Morphemic structures of words are usually described with the help of models, in which Latin letters denote functional type of a morph, e.g., вu/uиm/к/a PRSF. The basis of such modelling is a fundamental linguistic idea: a composition formula, which is regularly repeated and reproduced in language, is defined as a special unit of language structure along with phoneme and morpheme [11]. This methodological principle was taken as a basis for computer modelling of structural-functional connections of morphs in a word during compilation of MDB.

\subsection{Computer Modelling of Morphemic Structures of Words}

MDB is a list of Ukrainian words segmented into morphs. A basic list unit of MDB is a word with software procedure of determination of morphemic word structure (задньоязиковий RDSFIGRLSNFP), which models the morphemic structure of the given word (зад-нь-о-язик-ов-ий RSIRSF).

In the first stage of processing of the MDB lexical list, the automatic retransmission of literal word record into a simplified phonemic record takes place. The algorithm of retransmission of literal record into a simplified phonemic one takes into account only the positions of sounds that are pronounced with iotacism: $\mathbf{9}$, ю, $\mathbf{\epsilon}, \mathbf{i}$ : makes the conversion $\mathbf{c}$ à je, ï à ji. This procedure is obligatory, since it makes it possible to define the boundary of morphs, when the one-letter spelling for 
two sounds appears at the junction of morphs: клё̈ти à клеј-і-ти. All the other peculiarities of a phonemic record are not taken into account.

Morphemic analysis of lexicon (initial word forms) takes place on the second stage. In MDB, each word has an ascribed model according to the methodology of computer modelling of structural-functional connections of morphs in a word. This model determines boundaries and functional type of morphs, and at the same time it is a formula of software procedure of morphemic word segmentation. E.g., 3ad/ $\mathrm{mb} / \mathrm{o} /$ язик/ов/ий R3S5I6R10S12F14: Latin letters denote a functional type of a morph: $\mathrm{P}$ - prefix, $\mathrm{R}$ - root, $\mathrm{S}$ - suffix, F - ending, I - interfix, X - postfix, and the numbers denote boundaries of a morph with a sequence number (from the beginning of a word) of a terminal letter of each morph. The formalized description of morphemic word structure in terms of software procedure represents functional pattern of word structure at morphemic level - RSIRSF; the substantial (literal) representation of this structure is presented in the form of quantitative-literal model (зад $-3 ;$ нь $-5 ;$ о -6 ; язик - 10; ов - 12; ий - 14). Literal-number boundaries of morphs in the database are automatically converted into Latin letters: R3S5I6R10S12F14 = RDSFIGRLSNFP. The morphic structure, which is automatically formed with the help of a software procedure, gives full linguistic information about a morph, its structural and distributional relations with other morphs, and it is defined as a working unit of a dictionary of morphs.

The MDB list looks like an automatic dictionary:

безсонниия,К,PDRGSHSJFK/сон2/

безсонячний,A,PDRGSISJFL/сон1/

дисонанс, Й,PCRFSIFJ/сон3/,

where each word has an ascribed linguistic information about: a grammatical code of a word ( $\mathrm{K}$ - feminine noun; $\mathrm{H}$ - adverb, etc.); a model of software procedure of word segmentation into morphemes (PDRGSHSJFK; PDRGSISJFL); a root index in case of its homonymy or allomorphy (/сон $1 /$; /сон2/; /сон3/).

\section{THE USE OF ASMDA IN COMPUTER LEXICOGRAPHICAL TASKS}

\subsection{ASMDA as an Electronic Information System of Morphemics of Ukrainian Language}

The software of ASMDA performs operations of automatic classification of Ukrainian language lexicon within the MDB lexical list ( $\approx 200000$ words) according to different parameters of morphemic word structure organisation: quantity of morphemes in a word; models of morphemic structures; specified affix or root morph. The ASMDA software also automatically compiles the lists of prefixes, roots, suffixes, interfixes, postfixes and endings (the system of endings is compiled with restriction, only on the basis of initial word forms).

ASMDA also performs the functions of the linguistic classifier in the process of compiling of an electronic derivational dictionary. The system of automatic derivational analysis is designed on the basis of this linguistic classifier. The formation of a derivational word family as an item of the electronic derivational dictionary is carried out on the basis of selection of all words from the MDB. The 
formation of selections of words having the same root is a difficult and laborious task, thus it is necessary to formalise the material on all the stages of its description, it enables to create software tools of the linguistic analysis.

Taking into account principles of derivation formalising principles of description of derivational relations between motivating and motivated words were designed. It enables to build the hypothesis-model in operation of a derivational word family. In this hypothesis-model every following word building act represents words with more complex affixal structures of stems in terms of quantity; i.e., a group of words of an each quantitative and affixal model of a word is a hypothetic stage of a derivational word family.

A linguist carries out further construction of a derivational word family automatically by means of toolset of the electronic card (see Fig. 2). This example demonstrates the part of the derivational word family of the words with the root голод-, which is constructed by a linguist in automated mode on the basis of the selection of the words having one root of the morphemic database.

Each branch of the derivational tree reflects the relations of derivational motivation between the main word, which is marked by a square with either + or -, and the words that finish the branches of this main word. Marker "+" denotes that the word is the main one, i.e. that it is a starting point of the branch, while the marker "_."denotes that this branch is already extended. The modelling structural and motivational relations between the words of neighbouring derivational stages is carried out by means of establishing correspondences between numeric codes of words which belong to the morphemic database: голодувати а̀ голодування, голодувати а̀ поголодувати.

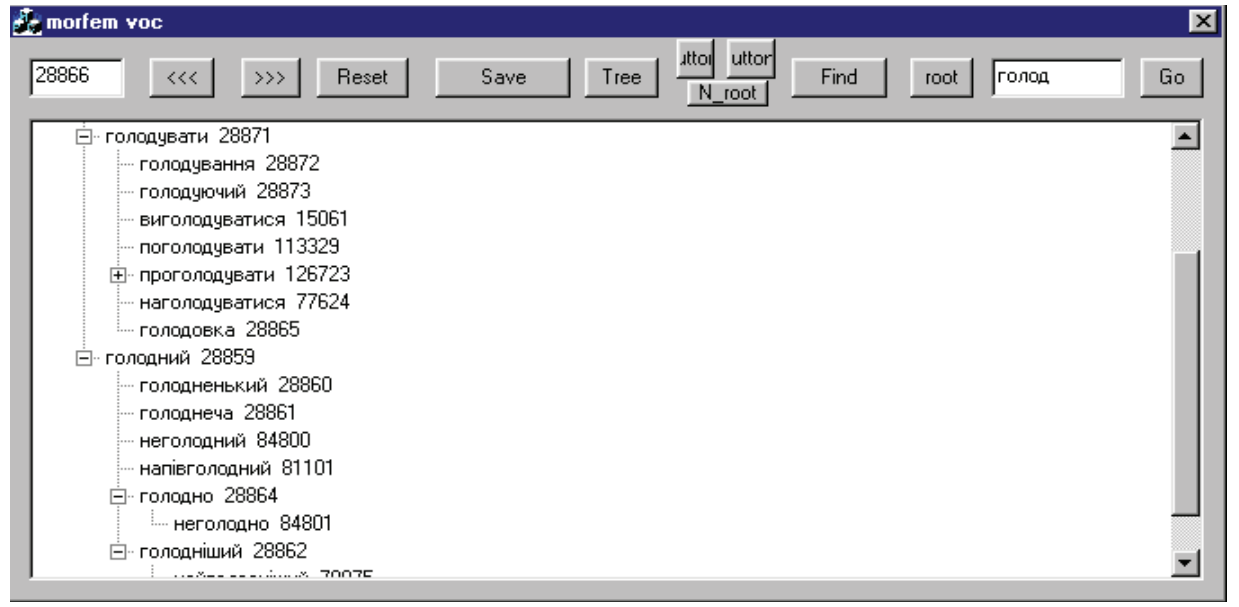

Fig. 2. Interface of the derivational word family

Philologists of Taras Shevchenko National University of Kyiv actively use ASMDA as an information system of morphemics and word formation of Ukrainian language in different scientific research projects, although this database is not a lexicographical product for a wide range of users. That is why the staff of Computational Linguistics Laboratory started to work on the creation of 
lexicographical system "Morphograph", which will be presented online as a public information resource for the users-philologists.

\subsection{ASMDA as an Automatic Morphemic Segmentator of Ukrainian Text Tokens}

Since the beginning of its creation, the system of ASMDA has been focused on automatic morphemic segmentation of text tokens. The morphemic segmentator of the Ukrainian text is a system, which on the input has the word forms of the analysed text with defined grammatical codes, which have been ascribed to the forms as a result of morphological annotation of text. On the output there are the same word forms split into morphs with proper indexes ascribed to each defined morph $(\mathrm{P}-$ prefix, $\mathrm{R}$ - root, $\mathrm{S}$ - suffix, F - ending, I - interfix, $\mathrm{X}$ - postfix).

\begin{tabular}{|c|c|c|c|c|}
\hline id & cls & morfem & morfema & comm \\
\hline 378422 & חा & $\mathrm{R}$ & $3 a$ & 3a|RC|RC \\
\hline 378423 & ЙИ & $\mathrm{R}$ & щит & щитом | RDFE | RDFF \\
\hline 378424 & йи & $\mathrm{F}$ & OM & щитом | RDFE | RDFF \\
\hline 378425 & $\mathrm{~A} И$ & $\mathrm{R}$ & смарагд & смарагдових | RHSJFL | RHSJFL \\
\hline 378426 & $\mathrm{~A} И$ & $S$ & $\mathrm{OB}$ & смарагдових | RHSJFL | RHSJFL \\
\hline 378427 & AИ & $F$ & $n x$ & смарагдових | RHSJFL | RHSJFL \\
\hline 378428 & ЙИ|न & $\mathrm{R}$ & תic & лісів | RDFE | RDFF \\
\hline 378429 & ЙИ| & $\mathrm{F}$ & iв & лісів | RDFE | RDFF \\
\hline 378430 & & $N$ & & \\
\hline
\end{tabular}

Fig. 3. A fragment of the morphemic annotation database of Ukrainian text

Fig. 3 shows the morphemic segmentation of the text fragment's tokens ...3a щзитом смарагдових лісів. Each token is automatically segmented into morphs with automatic ascription of two software procedures ( $5^{\text {th }}$ column): the first one is a morphemic model of the initial word form of the lexeme; the second one is a morphemic model of the text fragment's word form. The morphemic segmentation is performed according to the procedure of comparison of initial forms and text's word forms on the basis of two databases: a morphemic database and a morphological database of the system for automated grammatical text analysis.

\subsection{ASMDA as an Automatic Morphemic Analyser in the Corpus of the Ukrainian Language}

While creating the automatic morphemic analyser in the Corpus of the Ukrainian language, we have rejected the method of morphemic text annotation for the purpose of search optimization in large text databases. There is no morphemic annotation of text tokens, the corpus texts are only a source for compilation of different alphabetic-frequency dictionaries of morphemic based on vocabulary samples of the corpus texts; the ASMDA performs the function of morphemic analyser-module. 


\begin{tabular}{|c|c|c|c|c|c|c|c|c|c|c|c|c|c|c|c|c|}
\hline Таблицы & v $\|$ & 4 & KOA & - & wrd & ds & . & xabs & . & xsred & sigma & V & $R$ & - context . & $d$ & morfem \\
\hline 南 classes & & & & 396 & вгасати & 「 & & & 2 & 0,0327868852 & 0,1780783687 & 5,4313902456 & & 2 Tліе, не вгаса & 2,988105 & 5 PRSF \\
\hline 网 frea & & & & 397 & вголос & H & & & 1 & 0,0163934426 & 0,1269830605 & 7,7459666924 & & 1 А то думають & $1,110223 \mathrm{E}-15$ & $5 \mathrm{PR}$ \\
\hline - ine्य & & & & 398 & вгородити & r & & & 1 & 0,0163934426 & 0,1269830605 & 7,7459666924 & & 1 Вихватилатус с & 1,110223E-15 & 5 PRSF \\
\hline$\boxplus$ freq_wf & & & & 399 & вropy & H & & & 4 & 0,0655737705 & 0,5079322421 & 7,7459666924 & & 1 Все вгору та вІ & 1,110223E-15 & 5 PRS \\
\hline info & & & & 400 & вдавити & 「 & & & 1 & 0,0163934426 & 0,1269830605 & 7,7459666924 & & 1 Чому мене не & $1,110223 \mathrm{E}-15$ & 5 PRSF \\
\hline 目 Kodes & & & & 401 & вдарити & $r$ & & & 2 & 0,0327868852 & 0,1780783687 & 5,4313902456 & & 2 Налигачем Скғ & 2,988105 & 5 RSF \\
\hline
\end{tabular}

Fig. 4. Fragment of morphemic database of initial word forms

On the stage of morphological module performance all the text tokens with morphological annotation are lemmatized into the initial forms, and then they enter the morphemic module in the form of the alphabetic-frequency dictionary of initial forms including information about a part of speech, frequency characteristics and contextual usage. A morphemic model of the word is ascribed to the initial forms in the morphemic module on the basis of comparison with this word in MDB (see Fig. 4).

A new database is compiled on the output of morphemic module; this database includes the same systematized initial word forms, which have been segmented into morphs, containing information about a functional type of morpheme (Fig. 5). The segmentation into morphs is carried out according to the rules of morphemic word structure organisation and the specified models of software procedures of word segmentation in the morphemic database of ASMDA.

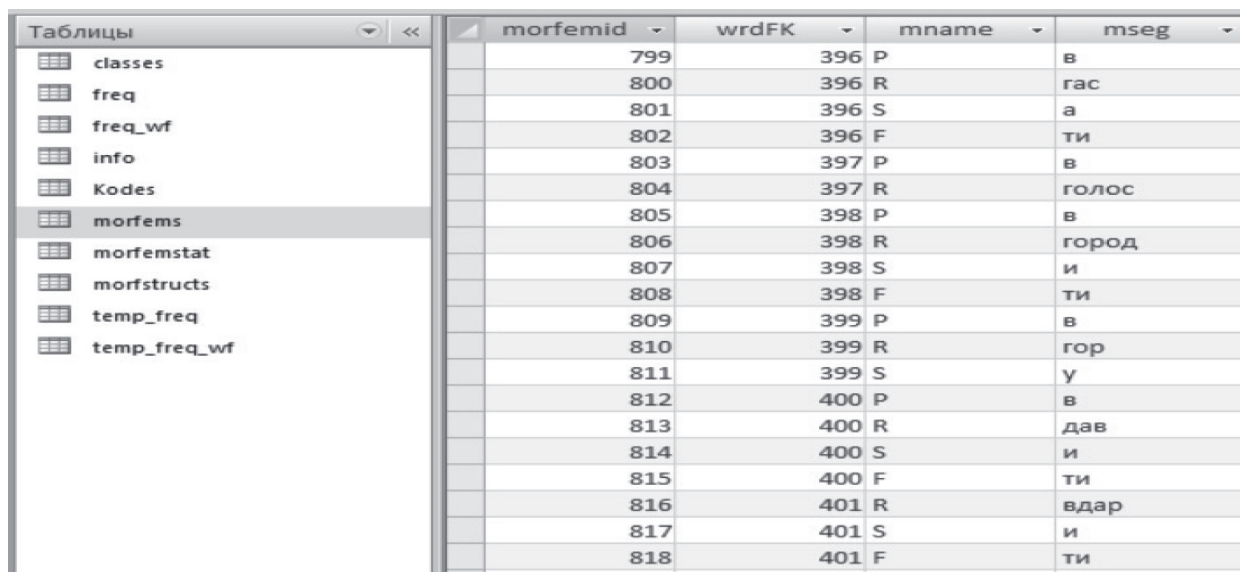

Fig. 5. Fragment of the database of morphemic segmentation of initial word forms

Different kinds of alphabetic-frequency dictionaries of morphemes and morphemic word structures are compiled on the basis of these databases according to the text samples of certain authors or style subcorpora. These dictionaries are presented in the corpus category of "Frequency Dictionaries" [4] as free-running electronic lexicographical systems. Today there are frequency dictionaries based on 13 text samples: frequency dictionaries of 9 authors, frequency dictionaries of opinion journalism, frequency dictionaries of artistic prose, frequency dictionaries of folklore texts, and frequency dictionaries of endocrinology. The dictionaries are structured into three zones combined by a comfortable navigation: 1. Inventory of units (morph structures, roots, affixes). 2. A token of a morph structure / morpheme in the text words according to the following characteristics: a) inventory and the 
number of words (lexemes) of each morph structure, root, affix; b) part of speech categorization of a word; c) absolute frequency of the word use (a number of lexeme tokens in texts); d) the number of texts (works), where the word is used; e) the average frequency of the word use; f) standard deviation; g) stability rate; 3. Contextual use of the analysed word (concordance).

For example, Electronic dictionary of frequency of morphemes [6], which was automatically constructed based on $\approx 80,000$ tokens of $T$. Shevchenko's poetic speech in the Corpus of the Ukrainian language. Inventory of units for the dictionary of frequency of morphemes is compiled automatically based on a user's choice. In the dropdown lists according to the two filters: 1) a type of morpheme, 2) a part of speech; a user may choose: 1) units of analysis, in our case - the roots; 2) morphological field of sample words: all the text words or the words of a one part of speech - nouns in the demo version.

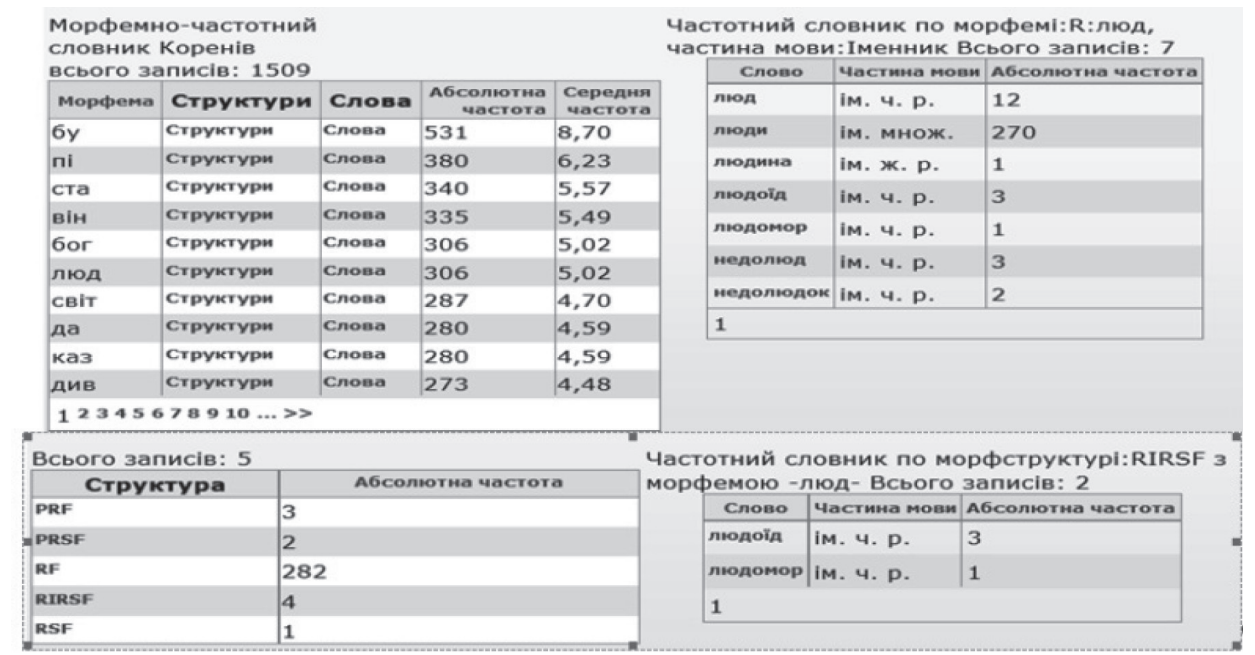

Fig. 6. A fragment of the Dictionary of frequency of roots

A fragment of the Dictionary of frequency of roots (Fig. 6) shows that the vocabulary of noun lexicon roots (zone 1) of T. Shevchenko's poetic speech contains 1,509 roots with information about the absolute and average frequency of each root's use in text tokens (in all text tokens regardless part of speech categorization of words). It is possible to create a root inventory according to the fall or rise of absolute frequencies.

The second zone of the dictionary presents the lexical token of specific root selected in the first zone: this fragment demonstrates the token of -люд-, a frequently used root (with an absolute frequency of 306 tokens) in noun tokens of the text. This root is materialized in 7 words with different productivity. The most frequent word is $л ю \partial и$, which occurs in poetic speech in 270 tokens of the text.

Activation of "Structure" option in the first zone opens the list of morphemic structure models of specific root (the third zone is the bottom left table), where the root -люд- is materialized. Activation of the specific morph-structure model opens 
the window of lexical realization of the specific structure (the fourth zone is the bottom right table). The fragment demonstrates the realization of RIRSF model of the root -люд- in two words: люд/о/ід/Ø/Ø, люд/о/мор/Ø/Ø.

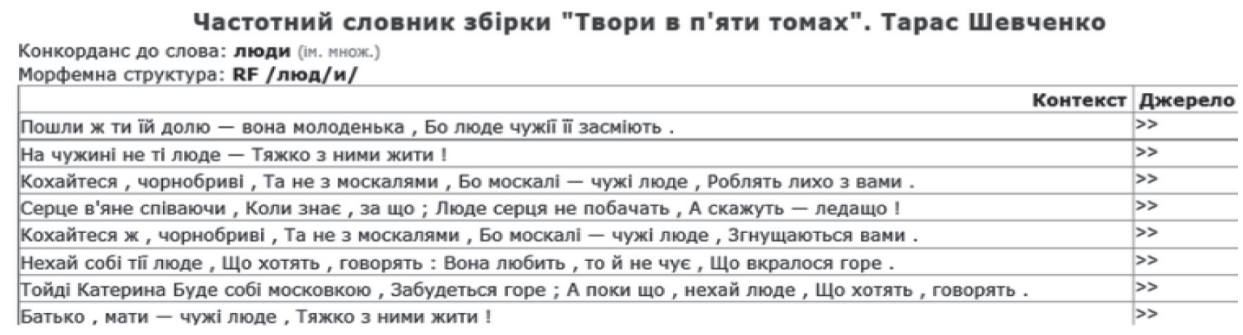

:ПРИЧИННА ("Реве та стогне Дніпр широкИЙ..."):ТВОРИ:ТАРАС ШЕВЧЕНКО:ПОЕТИЧНА

MOBA

Стиль:поетичні тексти

Приблизна кількість слововживань: 849

Видано:Киів: Дніпро:

Жанр: вірш

Мicuе: Україна / Росія: XIX cr.

Fig. 7. Text of the lexeme люди

Activation of the specified word in the "Dictionary of frequency of morphemes" (upper right table) opens the window of contextual word usage (Fig. 7). Each text fragment is connected to the extralinguistic information about the work by the function "Source" in the corpus: Fig. 7 demonstrates information about the work using the first quote of the concordance.

Automatic dictionary of frequency of morphemes word structures has the same arrangement: dictionary of frequency of morph-structures, realization of the specified morph-structure in the lexicon sample, realization of the word of the specified morph-structure in texts. Fig. 8 illustrates the realization of the high-frequency morph-structure PRSF (3,804 text tokens) in 95 nouns in the texts of T. Shevchenko.

The right upper table (Fig. 8) presents the model of PRSF morphemic word structure. According to the selection of each morph's index in this model ( $\mathrm{P}$ - prefix, $\mathrm{R}$ - root, $\mathrm{S}$ - suffix, $\mathrm{F}$ - ending) frequency dictionaries of morphemic are automatically compiled for those morphs, which occur in the sample vocabulary according to the model PRSF (bottom tables of the figure): prefixes, roots, suffixes, endings (only based on the initial word forms).

\section{CONCLUSION}

The use of ASMDA as an automatic morphemic segmentator of initial forms and a constructor of dictionaries of frequency of morphemes in the Corpus of the Ukrainian language reveals new research facilities of morphemic structure of Ukrainian words in a dictionary and in a text. The obtained statistics can be used in systemic stylistic research [12]: the comparison of frequency characteristics of morphemic units in different text samples of the corpus and in language system predicts realization expectancy of morphemic units in different texts, and formalizes 
the notion of statistical text structure at morphemic level as its stylometric model. Systematization of morph-structures allows to analyse the inclusion of morphemic models into the formation of new corpus vocabulary, to investigate morphemic length and intensity of words in Ukrainian texts of different styles as well as morphotactics of different morpheme types. The relation of dictionaries of frequency of morphemes to the concordance allows to analyse different aspects of morphemes and morph-structures functioning in sentences.

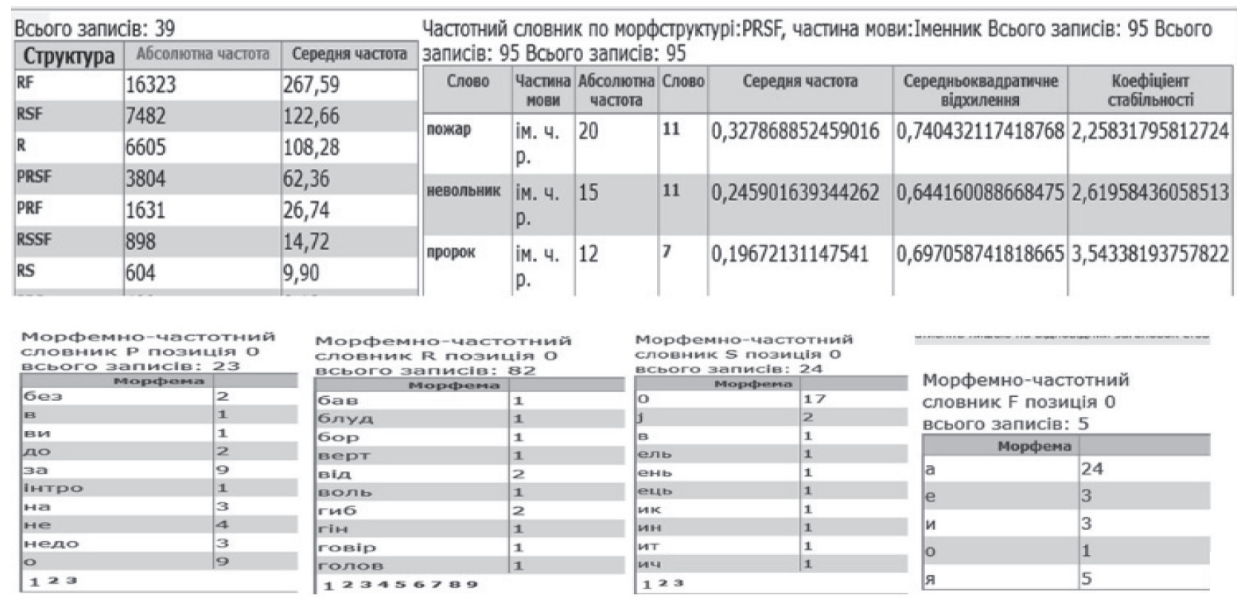

Fig. 8. Fragment of electronic dictionary of morph-structures

The experience of carrying out the automatic morphemic analysis demonstrates that it is not obligatory to create morphemic or word-formative annotation of texts for the purpose of retrieval of relational and functional characteristics of morphemic units from the text. The methodology for morphemic annotation of lexeme dictionary of texts (the initial forms) does not reduce efficiency and immediacy in linguistic research; on the contrary, it increases resolution capacity of research due to systematization and various classification of morphemic information. A study of text organization at morphemic level by means of morphemic analysis of initial word forms instead of tokens is justified by experience in compilation frequency dictionaries of morphemic in the Corpus of the Ukrainian language. The approach is based on ontological organization of morphemic word structure of inflected languages: the morphemic structure of the word stem representing explicit word semantics remains relatively stable during inflection. The quantity of morphemes does not change, only inflectional allomorphy may appear, but it is taken into account during lemmatization and may be automatically ascribed to morphemes as a potential feature. The use of morphemic annotation methodology of dictionary of the initial word forms in the Corpus of the Ukrainian language demonstrates efficiency and optimality of this methodology: $\approx 200,000$ units of the ASMDA morphemic database allow to obtain information about morphemic structure of $\approx 50$ million text tokens with illustration of their contextual usage. The disadvantage of this methodology is impossibility to remove word homonymy of one part of speech in case of different morphemic 
segmentation of homographs: вида-mu (to print), ви-да-mu (to hand), вид-a-mu (to see). In such cases morphemic segmentation is edited manually.

The development of ASMDA at this stage sets the task of automatic compilation of conjugate samples on the basis of ASMDA lexical list taking into account homonymy and allomorphy of roots, as well as compilation of common-affix samples taking into account homonymy and allomorphy of affixes. There is work underway to verify the database of homonymic and allomorphic roots and to compile a database of homonymic and allomorphic affixes. The methodology of computer modelling in the process of ASMDA construction summarizes theoretical and applied ideas of modern linguistics, which makes this system an efficient and rational tool for linguistic research.

\section{References}

[1] Alekseenko, L. A. et al. (2004). Parametrizirovannaya baza dannykh poeticheskoy rechi kak istochnik i instrument filologicheskikh studiy. In Mezhdunarodnaya konferentsiya "Prikladnaya lingvistika bez granits". Materialy konferentsii, pages 80-87, Sankt- Peterburg.

[2] Aleksijenko, L. A., Darčuk, N. P., and Zuban', O. N. (2001). Metodyka stvorennja avtomatyzovanoji systemy morfemno-slovotvirnoho analizu (ASMSA) sliv ukrajins'koï movy. In Naukova spadščyna profesora S. V. Semčyns 'koho. Zbirnyk naukovych prac', pages 38-49, Kyiv.

[3] Bogdanov, S. I. (1997). Forma slova i morfologicheskaya forma. Izd. Sankt-Peterburgskogo universiteta, Sankt-Peterburg.

[4] Častotni slovnyky Korpusu. Accessible at: http://www.mova.info/article. aspx? $11=210 \& D I D=5215$, retrieved 2017-03-15.

[5] Darčuk, N. (2013). Komp"juterne anotuvannja tekstu: rezul'taty i perspektyvy: monohrafija. Kyiv.

[6] Elektronnyj slovnyk movy T. Ševčenka. Accessible at: http://www. mova.info/cfqsh. aspx, retrieved 2017-03-15.

[7] Jacenko, I. T. (1980 - 1981). Morfemnyj analiz: Slovnyk-dovidnyk . Kyiv. T. 1-2.

[8] Klymenko, N. F. et al. (2014). Morfemno-slovotvirnyj fond ukrajins'koji movy jak doslidnyc'ka ta informacijno-dovidkova systema. In Klymenko N. F. Vybrani praci, pages 545-558, Kyiv.

[9] Korpus ukrajins'koji movy. Accessible at: http://www.mova.info/corpus.aspx, retrieved 2017-03-15.

[10] Kotova, N. V. and Yanakiev, M. O. (1978). O mnogoobrazii morfem v slavyanskikh yazykakh. Slavyanskaya filologiya, X:4-8.

[11] Solntsev, V. M. (1971). Yazyk kak sistemno-strukturnoe obrazovanie. Moscow.

[12] Zuban, O. (2016). Častotni morfemni slovnyky v Korpusi ukrajins'koï movy - džerelo stylemetryčnych doslidžen'. In Acta Universitatis Palackianae Olomucensis Philologica. UCRAINICA VII: Současná ukrajinistika. Problémy jazyka, literatury a kultury, pages 22-33, Olomouc.

[13] Zuban, O. (2015). Morphemic and derivational analysis in the corpus of the Ukrainian language. Ukrajins 'ke movoznavstvo, 1(45):3-10.

[14] Zuban, O. N. (2016). Zadachi i metody avtomaticheskogo morfemnogo analiza v Korpuse ukrainskogo yazyka. In Aktualnye problemy sovremennoy prikladnoy lingvistiki, pages 122-129, Minsk. 